\title{
Evaluation of biological control agents for managing squash powdery mildew under greenhouse conditions
}

\author{
Ahmed A. Elsisi ${ }^{1,2}$ (I)
}

\begin{abstract}
Squash (Cucurbita pepo L.), is one of the most important vegetable crops for human nutriment in Egypt and the world. One of the most serious diseases that infect squash and cause yield losses was powdery mildew, caused by Podosphaera xanthisii. The aim of this study was to investigate the role of Bacillus subtilis, Paenibacillus polymyxa $\left(10^{9}\right.$ cell $\mathrm{ml} / 1)$, Trichoderma harzianum, T. album, T. viride and T. hamatum ( $10^{7}$ spore $\left.\mathrm{ml} / \mathrm{l}\right)$ for controlling disease under greenhouse conditions. Results indicated that all treatments significantly inhibited the conidial germination of $P$. xanthii than control in vitro and decreased the incidence and disease severity after spraying with the bio-agents on squash plants under greenhouse conditions. The fungicide, Topas-100 (10.0\% penconazole "W/V" [(R,S-1-(2-(2,4dichlorophenyl)-Q pentyl)-1H-1,2,4-triazole]), followed by B. subtilis was highly significant for decreasing disease incidence (2.8 and 5.3\%, respectively) and disease severity percentage (3.5 and $4.8 \%$, respectively) than the control. The activities of biochemical changes, i.e., peroxidase, polyphenol oxidase, and total phenols, were significantly upregulated as results of most treatments. Also, bio-agent treatments caused significant increase in yield characteristics of squash plants such as fruit number/plant and fruit weight/plant than control. B. subtilis recorded the highest increase (110.9\% and 98.7\%) in fruit number and fruit weight/plant than control.
\end{abstract}

Keywords: Bacillus sp., Trichoderma sp., Powdery mildew, Squash, Antioxidant enzyme

\section{Background}

Squash (Cucurbita pepo L.), is one of the most important vegetable crops for human nutrition. It is a popular vegetable in Egypt and can be produced almost all year-round. Squash plants are infected by many diseases including anthracnose, Cercospora leaf spot, mosaic, downy mildew, Phytophthora crown rot, Septoria leaf spot, squash mosaic, Verticillium wilt, and powdery mildew which severely reduce their productivity (Gordon 2018). Powdery mildew (Podosphaera xanthii) is considered the most serious disease causing yield losses, as it affects the leaves, stems and fruits of squash grown under different conditions (Hafez et al. 2018). The fruit losses of squash estimated 30-50\% by attacking by Podosphaera xanthii El-Naggar et al. (2012).

Correspondence: ahmed.elsisi@fagr.bu.edu.eg

${ }^{1}$ Plant Pathology Department, Faculty of Agriculture, Benha University, Qalyubia, Egypt

${ }^{2}$ Toukh, Egypt
Chemical control alternative for powdery mildews disease by biological ways is environmentally friendly. In recent years, the development and resistance of pathogen cause of less effective of fungicides beside pollution and potentially undesirable effects of the chemical fungicides on human and environment (Manandhar et al. 1988). Successful biological control under greenhouse conditions on foliar diseases has been achieved by a number of researchers using fungal or bacterial bio-against (Hussein et al. 2007).

Gilardi et al. (2008) evaluated the activity of 2 bioagents mainly $B$. subtilis and A. quisqualis alone and in combination with the two fungicides penconazole and azoxystrobin against $P$. xanthii on zucchini (Cucurbita pepo L.) under controlled conditions. Abdel-Kader et al. (2012) reported that Trichoderma viride, T. harzianum, P. fluorescens, and B. subtilis reduced disease incidence of powdery and downy mildews of cucumber than the control. Use of bio-agents is safely and easily applied and cost-effective control treatment against plant foliar 
diseases. Trichoderma isolates have strong antagonistic and mycoparasitic effects against phytopathogens. Therefore, they are able to reduce disease severity in plants (Viterbo and Horwitz 2010; Elsharkawy et al. 2013).

Hafez et al. (2018) found that the bio-agents (Bacillus spp. and Trichoderma spp.) reduce significant disease severity of squash powdery mildew (Podosphaera xanthii). However, the bio-agent role could be attributed to upregulation of defense-related enzymes catalase, peroxidase, and polyphenol oxidase, which stimulate growth and yield characteristics to control. The fungicide Topas-100 one of systemic fungicides is more efficient in management of cucumber powdery and downy mildews (Abada et al. 2009). Disease severity of squash powdery mildew was reduced with an average of $10.34 \%$ when used the fungicide Topas-100 at recommended dose (El-Ghanam et al. 2018).

Here, we investigate the effect of six antifungal and bacterial bio-agents to reduce powdery mildew disease of squash that caused by $P$. xanthii under greenhouse conditions and their effects on the activity of defenserelated enzymes as well as the growth and yield of squash plants.

\section{Materials and methods}

\section{Source of bio-agents}

The efficacy of 2 bacterial bio-agents and 4 fungal strains comparing with the fungicide Topas-100 (10.0\% penconazole) for controlling squash powdery mildew disease under greenhouse conditions was estimated. Squash seeds 'cv. Eskandarani' were grown one seed per $15 \mathrm{~cm}$ pot. Bacillus subtilis and Paenibacillus polymyxa were isolated from the surface of healthy cucumber and squash leaves and identified according to Kamel (2003). The bacterial isolates were grown on nutrient broth (NB) for $48 \mathrm{~h}$ while fungal strains (Trichoderma harzianum, T. album, T. hamatum, and T. viridi) were obtained kindly from the Plant Pathology Research Institute., Agricultural Research Center (ARC), Giza, Egypt, and cultured on potato dextrose agar (PDA). Fungal strains (Trichoderma spp.) were grown for 10 days on PDA medium separately, then prepared spores and mycelial suspensions and adjusted to about $10^{7}$ spore $\mathrm{ml} / \mathrm{l}$ with sterilized water. while, B. subtilis and P. polymyxa were separately grown in (NB) medium in 250-ml flasks and kept on shaker for 3 days at $150 \mathrm{rpm}$. The pellets of used bacterial bio-agent were suspended in tap water and modified the number of cells to $10^{9}$ cell $\mathrm{ml} / 1$ by using a hemocytometer slide (Hafez et al. 2018). For assessment with 6 bio-agents, plants were sprayed by distilled water as a negative control and sprayed with Topas- 100 at the recommended dose of $0.25 \mathrm{ml} / \mathrm{l}$ for comparison.

\section{Disease management In vitro experiment}

The experiments were carried out in the laboratory of the Department of Plant Pathology, Faculty Agriculture, Benha University, Egypt. Conidial spores of P. xanthii were obtained from young sporulating lesions, the lesions were softly shaken by glass bar, and new conidia were dropped on glass slides according to Nair et al. (1962): "Slides were previously cleaned by ethyl alcohol and air dried before covering with thin smears of $2 \%$ water agar, amended with filter-sterilized culture filtrate of the tested antagonist. Slides were placed on V-shaped glass rods in sterilized Petri-dishes, containing several layers of water-moistened filter papers". Slides with conidia were incubated at $25{ }^{\circ} \mathrm{C}$ for $24 \mathrm{~h}$ under continuous light (Reifschneider et al. 1985). Conidia were considered to have germinated, if a germ tube, at least as long as the width, was produced (Menzies et al. 1991). Percentages of germination were calculated for 100 conidia on a slide at $\times 100$ magnification. Three slides were examined for each treatment. Agar-free culture filtrate slides were used as a control treatment.

\section{Greenhouse experiments}

Squash seeds (Cucurbita pepo L., cv. Eskandarani) were sown in a clay soil at the rate of 3 seeds per hill under the experimental greenhouse conditions $\left(28^{\circ} \mathrm{C}, 85 \% \mathrm{RH}\right.$, and $12 \mathrm{~h}$ photoperiod). The experiment was conducted in a randomly complete block design, with 3 replicated plots for each treatment. Squash plants in all plots received all the recommended agricultural practices. Natural infection with $P$. xanthii conidia, the causal agent of squash powdery mildew, was conducted under greenhouse conditions. Infected plants used as inoculum source (susceptible host Eskandarani) were uniformly inoculated by freshly collected conidia by placing heavy infected plants of squash which are sensitive to $P$. xanthii inoculation according to the method described by (Hafez et al. 2018). In addition, plants were sprayed with 2 bacterial bioagents, 4 fungal strains and the fungicide Topas- 100 at recommended dose as mentioned before. Plants sprayed with sterilized tap water were used as control treatment.

\section{Disease assessment}

Squash plants after 45 days were examined periodically and the disease measures were determined using the devised scale (0-5) according to El-Ghanam et al. (2018) where $0=$ no symptoms appear, $1=0.1$ to $3 \%$ of leaf area covered by the infection, $2=$ more than 3 to $10 \%$ of leaf area covered by the infection, $3=$ more than 10 to $25 \%$ of leaf area covered by the infection, $4=$ more than 25 to $50 \%$ of leaf area covered by the infection, $5=$ more than $75 \%$ of the plant growth covered by the infection and the plants turned to be stunted. 
The disease incidence and the severity of the disease were recorded using the following formula:

$$
\text { Disease severity }(\%)=\Sigma(\mathrm{nxv}) / 5 \mathrm{~N} \times 100
$$

where $n=$ number of infected leaves in each category, $v$ = numerical values of each category, and $N=$ total number of the infected leaves.

Disease incidence $(\%)=$ no. of infected plants/total no. of the plants assessed $\times 100$

\section{Biochemical assay}

\section{Estimation of total phenolic compounds}

One gram of squash leaves sample was extracted by 10 $\mathrm{ml}$ of $80 \%$ methanol at $70^{\circ} \mathrm{C}$ for $15 \mathrm{~min}$. Then phenolic compounds were determined using the colorimetric method of analysis by Folin-Ciocalteu reagent described by Zieslin and Ben-Zaken (1993).

\section{Determination of peroxidase}

Peroxidase activity was determined according to the method described by Allam and Hollis (1972). Peroxidase activity was expressed as the increase in absorbance at $430 \mathrm{~nm} /$ gram fresh weigh/15 min.

\section{Determination of polyphenol oxidase}

Polyphenoloxidase activity was determined according to a modification of Ishaaya (1971). The phenol oxidase activity was determined as O.D. units $\times 10^{3}$ at an absorbency of $405 \mathrm{~nm}$.

\section{Effect of use bio-agents on total yield/plant of squash plants}

Average numbers and weights of fruits plant were recorded after harvesting fruits at marketable size. The squash fruits from each replicate of each treatment were collected twice a week, after 45 to 90 days from sowing, and the accumulated yield was expressed as the number and weight of fruits per plant.

\section{Statistical analysis}

Data were statistically analyzed using the (F) test and the value of LSD (at 5\%) according to Gomez and Gomez (1984).

\section{Results and discussion}

Efficacy of bio-agents on spore germination of Podosphaera xanthii

The efficacy of Bacillus subtilis, Paenibacillus polymyxa, Trichoderma album, T. harzianum, T. viride, and T. hamatum on percentage of Podosphaera xanthii (syn. Sphaerotheca fuliginea) spores' germination was evaluated under laboratory conditions compared with the fungicide Topas-100.

Data in Table 1 indicate that all tested treatments reduced significantly the percentage of conidial germination than the control. The high reduction was induced by Topas-100, which recorded $98.5 \%$, followed by $P$. polymyxa $88.0 \%$ and B. subtilis $82.0 \%$, whereas, $T$. viride and $T$. hamatum reduced conidial germination by $79.2 \%$ and $78.9 \%$, respectively. On the contrary, T. album was the least effective treatments. The production of antimicrobial metabolites was another biocontrol mechanism that can be associated with mycoparasitism. The Trichoderma isolates produced metabolites in liquid medium. This extract inhibited pathogen growth on plate in low percentages (Sanchez et al. 2019). Obtained results are in agreement with many researchers who found that the bio-agents studied were effective for controlling powdery mildew disease (Kamel 2003; García-Gutiérrez et al. 2013; Tanaka et al. 2017).

\section{Effect of using bio-agents under greenhouse conditions}

Results in Table 2 show that all tested treatments significantly reduced the percentage of the disease incidence and severity than the control. In this respect, treatments with the fungicide Topas-100 followed by B. subtilis were the highest significant ones for decreasing disease incidence (2.8 and 5.3\%, respectively) and disease severity percentage (3.5 and 4.8\%, respectively). Moreover, $T$. harzianum treatments caused significant decrease in

Table 1 Effect of some bio-agent on spores' germination of Podosphaera xanthii, in vitro

\begin{tabular}{llll}
\hline Treatment & Concentration & Germination (\%) & Efficiency (\%) \\
\hline B. subtilis & $10^{9} \mathrm{cfu}$ & 12.0 & 82.0 \\
Paenibacillus polymyxa & $10^{9} \mathrm{cfu}$ & 8.0 & 88.0 \\
Trichoderma album & $10^{7} \mathrm{spores} \mathrm{ml}^{-1}$ & 20.3 & 69.6 \\
Trichoderma harzianum & $10^{7} \mathrm{spores} \mathrm{ml}^{-1}$ & 19.2 & 71.3 \\
Trichoderma viride & $10^{7} \mathrm{spores} \mathrm{ml}^{-1}$ & 13.8 & 79.2 \\
Trichoderma hamatum & $10^{7} \mathrm{spores} \mathrm{ml}^{-1}$ & 14.1 & 78.9 \\
Topas-100 & $0.25 \mathrm{mll}^{-1}$ & 0.9 & 98.5 \\
Control & - & 66.9 & 0.0 \\
L.S.D. at 5\% & & 14.8 & - \\
\hline
\end{tabular}


Table 2 Effect of spraying bio-agent to control powdery mildew disease on squash plants under greenhouse conditions

\begin{tabular}{lllll}
\hline Treatment & Disease incidence \% & Efficacy \% & Disease severity \% & Efficacy \% \\
\hline B. subtilis & 5.3 & 93.6 & 4.8 & 14.5 \\
Paenibacillus polymyxa & 27.7 & 66.7 & 10.0 & 81.9 \\
Trichoderma album & 13.9 & 83.3 & 6.6 & 87.5 \\
Trichoderma harzianum & 8.3 & 90.0 & 11.6 & 91.8 \\
Trichoderma viride & 15.9 & 80.9 & 18.3 & 85.6 \\
Trichoderma hamatum & 25.0 & 69.9 & 3.5 & 77.2 \\
Topas-100 & 2.8 & 96.6 & 80.5 & 95.7 \\
Control & 83.3 & 0.0 & 3.96 & 0.0 \\
L.S.D. at 5\% & 4.10 & - & & - \\
\hline
\end{tabular}

disease incidence percentage $(8.3 \%)$ and efficacy was 90.0\%. Meanwhile, the bioagent $P$. polymyxa was the lowest efficient ones, with $66.7 \%$. These results agree with the findings of Gilardi et al. (2008) and ElSharkaway et al. (2014) who used Bacillus sp. for controlling cucurbit powdery mildew. Hence, B. subtilis played an important role on plant growth-promoting rhizobacteria that is widely applied to management the highest reduction of disease severity of many crop diseases (Liu et al. 2014).

Also, Trichoderma spp. produce antifungal compounds which acted synergistically for reducing the disease severity of powdery mildew disease of squash plants (El-Kot and Derbalah 2011). Priming of plants with Trichoderma spores or Trichoderma secondary metabolites produced rapid and effective defense responses against pathogen attack by acting as immunity stimulants (Contreras-Cornejo et al. 2011; Tucci et al. 2011; Elsharkawy et al. 2012; Yoshioka et al. 2012).

The fungicide (Topas-100) as a systemic fungicide is more efficient in management of many fungal diseases, including powdery and downy mildews in Cucurbits (Abada et al. 2009; Hafez et al. 2018).

\section{Effect of some bio-agents on biochemical changes of squash plants}

Results in Table 3 revealed that all treatments increased the activity of peroxidase than in control treatment. The highest activity of peroxidase was induced by $P$. polymyxa (262.3), followed by $T$. viride and B. subtilis recording 194.3 and 180.7, respectively. Meanwhile, Topas-100 was the least effective one. On the other side, the highest level of polyphenol oxidase was recorded after treatments by $T$. album, $P$. polymyxa, and $T$. viride recording 131.3, 123.7, and 114.0, respectively. While $T$. harzianum was the least effective one in respect of the effect of different bio-agents on total phenols content, the highest total phenols content was recorded in plants treated with $T$. viride (75.9), followed by Topas-100 (61.6) and $T$. harzianm (54.6), while $T$. hamatum showed the least effect on total phenols content. Sprayed plants recorded best results for most growth characters, peroxidase, polyphenol oxidase, and total phenols enzymes activity compared with untreated one )Hegazi and El-Kot 2010). Many investigators supported this idea since they stated that there are positive relationships between peroxidase enzyme and resistance developed in plants (Nawar and Kuti 2003; Emeran et al. 2006).

Table 3 Effect of some bio-agent on biochemical changes of squash plants

\begin{tabular}{llll}
\hline Treatment & $\begin{array}{l}\text { Peroxidase } \\
\left(\boldsymbol{\Delta}_{405} \text { D. } \times 10^{3} / \mathrm{min} / \mathrm{g} \text { fresh weight) }\right.\end{array}$ & $\begin{array}{l}\text { Polyphenol oxidase } \\
\text { (O.D. units } \times 10^{3} / \mathrm{min} / \mathrm{g} \text { fresh weight) }\end{array}$ & $\begin{array}{l}\text { Total phenols } \\
(\mu \mathrm{g} \text { GAE/g fresh weight) }\end{array}$ \\
\hline B. subtilis & 180.7 & 84.3 & 50.8 \\
Paenibacillus polymyxa & 262.3 & 123.7 & 48.6 \\
Trichoderma album & 151.7 & 131.3 & 45.7 \\
Trichoderma harzianum & 179.0 & 82.3 & 54.6 \\
Trichoderma viride & 194.3 & 114.0 & 75.9 \\
Trichoderma hamatum & 159.3 & 108.3 & 44.9 \\
Topas-100 & 147.3 & 84.3 & 61.6 \\
Control & 56.1 & 23.4 & 14.0 \\
L.S.D at 5\% & 84.9 & 27.6 & 11.6 \\
\hline
\end{tabular}


Table 4 Effect of bio-agents on the total yield/plant of squash plants under greenhouse

\begin{tabular}{|c|c|c|c|c|}
\hline \multirow[t]{2}{*}{ Treatment } & \multirow{2}{*}{$\begin{array}{l}\text { No. } \\
\text { fruits } \\
\text { plant }\end{array}$} & \multirow{2}{*}{$\begin{array}{l}\text { Total } \\
\text { yield/ } \\
\text { plant } \\
(\mathrm{kg})\end{array}$} & \multicolumn{2}{|l|}{ Efficacy \% } \\
\hline & & & No. fruits plant & Total yield/plant $(\mathrm{kg})$ \\
\hline B. subtilis & 19.8 & 1.5 & 110.9 & 98.7 \\
\hline Paenibacillus polymyxa & 16.1 & 1.2 & 71.3 & 61.3 \\
\hline Trichoderma album & 13.6 & 1.0 & 44.7 & 36.0 \\
\hline Trichoderma harzianum & 18.3 & 1.4 & 95.0 & 81.3 \\
\hline Trichoderma viride & 14.5 & 1.0 & 54.3 & 45.3 \\
\hline Trichoderma hamatum & 15.4 & 1.2 & 63.8 & 54.7 \\
\hline Topas-100 & 17.5 & 1.3 & 86.2 & 74.7 \\
\hline Control & 9.4 & 0.8 & 0.00 & 0.00 \\
\hline L.S.D at $5 \%$ & 2.2 & 0.05 & - & - \\
\hline
\end{tabular}

\section{Effect of bio-agents on the total yield/plant of squash plants under greenhouse}

Data in Table 4 indicate that all tested treatments significantly increased the fruit number and fruit weight/ plant. The highest increase was recorded by $B$. subtilis (110.9 and 98.7\%), followed by T. harzianum (95.0 and 81.3\%) and Topas-100 (86.2 and 74.7\%), respectively. $T$. album was the least effective treatment in this respect. The biological activity mechanisms of bioagents and chemical fungicide that reduced disease severity, suppressed and improved the total yield of squash (Cardwell et al. 1997).

B. subtilis induces plant resistance to stress and produces several plant hormones that can improve plant growth (Han and Lee 2005). Several researches have showed that plants grown particularly under salt stress conditions and inoculated with $B$. subtilis had a higher plant growth, yield, and nutrient uptake (Bochow et al. 2001; Saleh et al. 2005).

Hafez et al. (2018) reported that bio-agent treatments significantly increased growth and yield attributes of squash plants. Also, they stated usage of $B$. subtilis could suppress squash powdery mildew and increase yield up to $92 \%$ and T. harzianum increased total yield/plant up to $75 \%$. Meanwhile, the fungicide increased total yield up to $45 \%$. Overall, the results showed an alternative use of fungicides and bio-agents to control squash powdery mildew disease and the increase in total yield per plant.

\section{Conclusions}

Based on obtained data it could be concluded that the bio-agent could significantly inhibited the conidial germination of $P$. xanthii than control in vitro and decrease the incidence and severity disease after spraying with the bio-agents on squash plants under greenhouse conditions, with stimulating growth and yield attributes in comparison to control.

\section{Acknowledgements}

The author would like to thank colleagues at Plant Pathology Department of Agricultural, Faculty of Agriculture, Benha University, Egypt.

\section{Author's contributions}

The author read and approved the final manuscript.

Funding

Funding is by Faculty of Agriculture, Benha University and authors.

Availability of data and materials

All data and materials are available.

Ethics approval and consent to participate

Ethics committee approved the research article and author agree (consent) to participate in this research article.

\section{Consent for publication}

The author participated in the work and Consent for publication.

\section{Competing interests}

The author declares that there are no competing interests.

Received: 30 June 2019 Accepted: 26 November 2019

Published online: 16 December 2019

\section{References}

Abada K, El-Alim A, Abd-Elbacki A, Ashour A (2009) Management of pea powdery mildew disease using some resistance inducing chemicals and systemic fungicides. Egypt J Phytopathol 37:95-104

Abdel-Kader MM, El-Mougy NS, Aly MD, Lashin SM, Abdel-Kareem F (2012) Greenhouse biological approach for controlling foliar diseases of some vegetables. Adv Life Sci 2(4):98-103

Allam Al, Hollis JP (1972) Sulfide inhibition of oxidase in rice roots. Phytopathology 62:634-639

Bochow H, El-Sayed SF, Junge H, Stauropoulou A, Schmieeknecht G (2001) Use of Bacillus substilis as biocontrol agent. IV. Salt-stress tolerance induction by Bacillus substilis FZB24 seed application in tropical vegetable field crops, and its mode action. J Plant Dis Prot 108:21-30

Cardwell K, Schulthess F, Ndemah R, Ngoko Z (1997) A systems approach to assess crop health and maize yield losses due to pests and diseases in Cameroon. Agric Ecosyst Environ 65(1):33-47

Contreras-Cornejo HA, Macias-Rodriguez L, Beltran-Pena E, Herrera-Estrella E, Lopez-Bucio J (2011) Trichoderma-induced plant immunity likely involves both hormonal- and camalex independent mechanisms in Arabidopsis thaliana and confers resistance against necrotrophic fungus Botrytis cinerea. Plant Signal Behav 6:1554-1563

El-Ghanam A, Rahhal M, Al-Saman M, Khattab E (2018) Alternative safety methods for controlling powdery mildew in squash under field conditions. Asian J Adv Agric Res 7(1):1-21 
El-Kot G, Derbalah A (2011) Use of cultural filtrates of certain microbial isolates for powdery mildew control in squash. J Plant Prot Res 51(3):252-260

El-Naggar M, El-Deeb H, Ragab S (2012) Applied approach for controlling powdery mildew disease of cucumber under plastic houses. Pak J Agric: Agric Eng Vet Sci (Pakistan) 28(1):54-64

El-Sharkaway MM, Kamel SM, El-Khateeb NM (2014) Biological control of powdery and downy mildews of cucumber under greenhouse conditions. Egypt J Biol Pest Control 24(2):407

Elsharkawy MM, Shimizu M, Takahashi H, Hyakumachi M (2012) The plant growth-promoting fungus Fusarium equiseti and the arbuscular mycorrhizal fungus Glomus mosseae induce systemic resistance against Cucumber mosaic virus in cucumber plants. Plant Soil 361:397-409

Elsharkawy MM, Shimizu M, Takahashi H, Ozaki K, Hyakumachi M (2013) Induction of systemic resistance against cucumber mosaic virus in Arabidopsis thaliana by Trichoderma asperellum SKT-1. Plant Pathol J 29:193-200

Emeran AA, Belal EB, El-Zahaby HM (2006) Biological control of faba bean chocolate spot disease caused by Botrytis fabae. J Agric Res Tanta Univ 32(2): $243-258$

García-Gutiérrez L, Zeriouh H, Romero D, Cubero J, Vicente A, Pérez-García A (2013) The antagonistic strain Bacillus subtilis UMAF6639 also confers protection to melon plants against cucurbit powdery mildew by activation of jasmonate- and salicylic acid-dependent defense responses. Microb Biotechnol 6(3):264-274

Gilardi G, Manker D, Garibaldi A, Gullino M (2008) Efficacy of the biocontrol agents Bacillus subtilis and Ampelomyces quisqualis applied in combination with fungicides against powdery mildew of zucchini. J Plant Dis Prot 115(5): $208-213$

Gomez K, Gomez A (1984) Statistical procedures for agricultural research, 2nd edn. Wiley, New York, p 680

Gordon N (2018) Controlling powdery mildew on cucurbit using biological control agents. PhD Thesis, Faculty of Agricultural. Tennessee State University, p 55

Hafez YM, El-Nagar AS, Elzaawely AA, Kamel S, Maswada HF (2018) Biological control of Podosphaera xanthii the causal agent of squash powdery mildew disease by upregulation of defense-related enzymes. Egypt J Biol Pest Control 28(1):57

Han HS, Lee KD (2005) Plant growth promoting rhizobacteria effect on antioxidant status, photosynthesis, mineral uptake and growth of lettuce under soil salinity. Res J Agric Biol Sci 1:210-215

Hegazi MA, El-Kot GA (2010) Biological control of powdery mildew on Zinnia (Zinnia elegans, L) using some biocontrol agents and plant extracts. J Agric Sci 2(4):221

Hussein MAM, Hassan MHA, Allam ADA, Abo-El-Yous KAM (2007) Management of stemphylium blight of onion by using biological agents and resistance inducers. Egypt J Phytopathol 35(1):49-60

Ishaaya I (1971) In the armored scale Aonidiella aurantii and observation on the phenoloxidase system Chrysomphalus aonidum. Comp Biochem Physiol 39(B):935-943

Kamel S (2003) Antagonistic effects of some microbial inhabitants on phylloplane of squash plants towards Sphaerotheca fuliginea. M. Sc. Thesis, Fac. Agric. Tanta, Univ, Egypt, p 94

Liu HX, Li SM, Luo YM, Luo LX, Li JQ, Guo JH (2014) Biological control of Ralstonia wilt, Phytophthora blight, Meloidogyne root-knot on bell pepper by the combination of Bacillus subtilis AR12, Bacillus subtilis SM21 and Chryseobacterium sp. R89. Eur J Plant Pathol 139(1):107-116

Manandhar JB, Hartman GL, Sinclair JB (1988) Soybean germplasm evaluation for resistance to Colletotricum truncatum. Plant Dis 72:56-59

Menzies JG, Ehret DL, Glass AD, Helmer T, Koch C, Seywerd F (1991) Effects of soluble silicon on the parasitic fitness of Sphaerotheca fuliginea on Cucumis sativus. Phytopathology (USA) 81:84-88

Nair KR, Sanaslvan, Ellingboe AH (1962) A method of controlled inoculations with condiospores of Erysiphe graminis var. Tritici. Phytopathology 52:417

Nawar HF, Kuti JD (2003) Wyerone acid phytoalexin synthesis and peroxidase activity as markers for resistance of broad beans to chocolate spot disease. J Phytopathol 151:564-570

Reifschneider FJ, Boitexu LS, Occhiena EM (1985) Powdery mildew of melon (Cucumis melon) caused by Sphaerotheca fuliginea in Brazil. Plant Dis 69: 1069-1070

Saleh SA, Heuberger H, Schnitzler WH (2005) Alleviation of salinity effect on artichoke productivity by Bacillus subtilis FZB24, supplemental Ca and micronutrients. Appl Bot Food Qual 79:24-32
Sanchez AD, Ousset MJ, Sosa MC (2019) Biological control of Phytophthora collar rot of pear using regional Trichoderma strains with multiple echanisms. Biol Control 135:124-134

Tanaka K, Fukuda M, Amaki Y (2017) Importance of prumycin produced by Bacillus amyloliquefaciens SD-32 in biocontrol against cucumber powdery mildew disease. Pest Manag Sci 73:2419-2428

Tucci M, Ruocco M, Masi LD, Palma MD, Lorito M (2011) The beneficial effect of Trichoderma spp. on tomato is modulated by the plant genotype. Mol Plant Pathol 12:341-354

Viterbo A, Horwitz BA (2010) Mycoparasitism. In: Borkovich KA, Ebbole DJ (eds) Cellular and molecular biology of filamentous fungi. American Society of Microbiology, Washington, pp 676-693

Yoshioka Y, Ichikawa H, Naznin HA, Kogure A, Hyakumachi M (2012) Systemic resistance induced in Arabidopsis thaliana by Trichoderma asperellum SKT-1, a microbial pesticide of seed borne diseases of rice. Pest Manag Sci 68:60-66

Zieslin N, Ben-Zaken R (1993) Peroxidase activity and presence of henolic substances in peduncles of rose flowers. Plant Physiol Biochem 31:333-333

\section{Publisher's Note}

Springer Nature remains neutral with regard to jurisdictional claims in published maps and institutional affiliations.

\section{Submit your manuscript to a SpringerOpen ${ }^{\circ}$ journal and benefit from:}

- Convenient online submission

- Rigorous peer review

- Open access: articles freely available online

- High visibility within the field

- Retaining the copyright to your article

Submit your next manuscript at $>$ springeropen.com 